\title{
Genetic Resources of Cynara spp. an AGR GEN RES European Project CYNARES
}

\section{A. Pagnotta ${ }^{1}$}

Summary. The European Commission (Directorate-General for Agriculture and Rural Development under Council Regulation (EC) No 870/2004), has sponsored the European Project 'CYNARES' for the characterisation and conservation of Cynara species germplasm, focusing predominantly on artichokes. The project (2008 - 2012) involves seven project partners from France, Spain and Italy which share European germplasm collections. The accessions are currently being assessed at the morphological, biochemical and molecular levels as well as for disease resistance. Policy aspects addressed within this project include patenting resources to increase value to farmers producing well-recognised varieties and with known nutriceutical values. Moreover, European germplasm will be assessed, classified and patented hence protected by the third country, to avoid fraud and valorise the European products; three clones have already been sent for evaluation by registration authorities in Italy. The conservation of Cynara spp. germplasm and its utilisation are crucial to the project and were developed based on the CBD, the FAO's GPA for PGRFA, and the ITPGRFA.

A CYNARES website documenting Cynara germplasm with project updating and information is available at: http://www.cynares.com/ or http://www.cynares.eu/. The site will also target farmers as well as other stakeholder needs. The website aims to be a focal point for all the activities related to Cynara spp. Anyone can register and contribute to the news updating, inserting scientific results, germplasm information or events announcement.

Key Words. CBD, Cynara diversity, ITPGRFA, network, PGRFA.

\section{Introduction}

The genus Cynara L. (Asteraceae, $2 \mathrm{n}=2 \mathrm{x}=34$ ) includes wild Mediterranean species and two crops. The botanical classification is not unequivocal, however: the classification developed by Wiklund (1992) divided the genus Cynara into eight species on the basis of the results of a crossing programme and isozyme analyses. Basnizki \& Zohary (1994), Rottenberg \& Zohary (1996) and Rottenberg et al. (1996) classified C. cardunculus L. into three varieties: the wild type var. sylvestris Lam. (wild cardoon), and two cultivated ones, var. scolymus (L.) Fiori (globe artichoke) and var. altilis DC. (leafy cardoon). This classification is also reported and confirmed by Sonnante and co-authors (2002, 2007a; b).

Globe artichoke is an allogamous and entomophilous plant, native to Southern Europe, around the Mediterranean basin and North-Western Africa. Southern Italy and Sicily have been recently identified as the origin of its domestication (Pignone \& Sonnante 2004; Sonnante et al. 2007a, b, 2008). Artichoke production is concentrated mainly in three countries: Italy (474,253 Mt), Spain (212,400 Mt) and Perù (134,244 Mt) (FAOSTAT 2007), followed by Argentina and Egypt.
The gene pool of artichoke is organised into four varietal types, 'Spinoso', 'Violetto', 'Romanesco', 'Catanese', and based on physical characteristics of the main flowering head (Porceddu et al. 1976; Vannella et al. 1981; Mauromicale \& Ierna 2000). Many populations of each type are still grown in various geographical districts, where they are usually named according to the locality of cultivation (Bianco 1990). This creates confusion in Cynara germplasm since the same material may have different names and vice versa. Protected Geographical Indication (PGI), a status appointed by the EU, could be a tool to protect European biodiversity and traditional food production (local products). The lines denominated as PGI include the Italian 'Romanesco del Lazio' globe artichoke (CE Reg. no. 2066/2002 of the Commission, published by GUCE no. L 318 of 22/11/2002) and the Spanish "Blanca de Tudela" (CE Reg no 1971/2001 of the Commission, 09/10/2001). The "Carciofo Romanesco del Lazio" includes several artichoke cultivars cultivated in Latium (Italy), all of them of Romanesco typology.

Thanks to the high content of various healthpromoting components (Mulinacci et al. 2004), artichokes are used also in the pharmacopoeia. The

Accepted for publication December 2010.

1 Università della Tuscia, Dipartimento Agrobiologia e Agrochimica, Via S. C. de Lellis, 01100 Viterbo, Italy. e-mail: pagnotta@unitus.it 